\title{
BAGAIMANA RAYAP DAPAT DIGUNAKAN SEBAGAI BIOINDIKATOR
}

\author{
TEGUH PRIBADI \\ Dosen Program Studi Kehutanan, Fakultas Pertanian, \\ Universitas PGRI Palangkaraya \\ e-mail : tgpribadi@gmail.com
}

\begin{abstract}
Ecosystem alterations not only affect habitat conditions but also have impact on biotic components. The presence of organisms provides response of habitat alteration can be used as indication organism. Indication organisms or bioindicator are key component in ecosystem management. This paper aims to evaluate and review the role of termites as bioindicator. Bioindicator defined as organisms or group of organism reflect and inform the ecosystem circumstance; environmental, ecological and biodiversity status as well as. Main criteria of bioindicator are as follow: taxonomical and biological characters of these organisms well-knew, cosmopolitan organisms, they have a well-response to habitat alteration, and their responses are closed correlated to all communities or properties of stress factors. Termites showed responses to environmental change, especially in habitat alteration. Termites responded to habitat alteration on termites composition change and termites richness decrease. Furthermore, termite's richness strong correlated with other taxon in their community. Biological and taxonomical termites are well-known. In addition, standard survey of termites has been developed to explore termite's richness in tropics ecosystems. These implication, termites can be applied as one of indication organisms or bioindicator, notably their relation in ecological indicator and biodiversity indicator.
\end{abstract}

Keywords : bioindicator, indicator value, ecosystemen management, habitat alteration, termites.

\begin{abstract}
ABSTRAK
Perubahan ekosistem tidak hanya mempengaruhi kondisi habitat tetapi juga berdampak pada komponen-komponen biotik. Keberadaan organisme yang mampu memberikan tanggapan sehingga dapat dijadikan sebagai organisme indikatif. Organisme indikatif atau bioindikator merupakan salah satu komponen penting dalam pengelolaan ekosistem. Makalah ini bertujuan untuk mengevaluasi dan mengkaji peranan rayap sebagai bioindikator berdasarkan kajian literatur yang ada. Bioindikator didefinisikan sebagai organisme atau kelompok organisme yang mampu memberikan gambaran dan informasi terhadap kondisi ekosistem baik berupa informasi kondisi lingkungan, ekologis dan keanakeragaman hayati. Persyaratan organisme bioindikator antara lain, informasi baik biologis dan taksonomis tersedia, bersifat kosmopolitan, memberikan tanggapan yang baik terhadap perubahan habitat, dan berkorelasi kuat dengan keseluruhan komunitas di habitat tersebut. Rayap memberikan tanggapan terhadap perubahan lingkungan, khususnya yang terkait dengan perubahan habitat. Rayap memberikan tanggapan terhadap perubahan habitat melalui perubahan komposisi jenis dan penurunan kekayaan jenis rayap. Selain itu, kekayaan jenis rayap berkorelasi kuat dengan kekayaan jenis beberapa takson yang lain. Biologi dan taksonomi rayap sudah tersedia dengan baik. Di samping itu, sigi baku keanekaragaman rayap sudah dikembang. Oleh karena itu, rayap dapat diterapkan sebagai salah satu organisme indikatif atau bioindikator terutama yang terkait dengan bioindikator ekologis dan bioindikator keanekaragaman jenis.
\end{abstract}

Kata kunci: bioindikator, nilai indikator, pengelolaan ekosistem, perubahan habitat, rayap. 


\section{PENDAHULUAN}

Aktivitas manusia dalam rangka penyejahteraan diri (human welfare) semakin meningkat. Kegiatan yang terkait dengan agenda manusia ini, menimbulkan interaksi antara manusia dengan lingkungannnya. Manusia mengeksplorasi dan mengeksploitasi sumber daya alam. Mereka mengubah, merusak bahkan menghilangkan ekosistem-ekosistem alamiah. Kawasan-kawasan berhutan dirubah menjadi lahan pertanian, perkebunan atau permukiman, sementara kawasan berair dan udara terbuka dijadikan muara berbagai bentuk zat tercemar. Manusia menciptakan teknologi dan membuat peralatan baru untuk mendukung keberadaan ekosistem-ekosistem ini. Bumi telah mengalami perubahan yang dramatis (Merkert et al. 2003). Perubahan ini telah melampaui batas kemampauan alamiah bumi untuk menyediakan sumber daya bagi manusia (Pankhurst et al. 1997) dan untuk memulihkan diri. Ekosistem, komunitas dan populasi termasuk manusia di dalamnya menanggung dampak negatif dari kerusakan lingkungan (Becker 2003).

Sistem ekologis bumi mengalami kerusakan seperti terjadinya erosi tanah, pengeringan sungai, kekacauan sistem neraca air, penyusutan hutan, instabilitas sistem cuaca dan punahnya beberapa spesies (Pankhurst et al. 1997). Bentuk kerusakan ekosistem ditandainya dengan: (1) intensitas serangan hama penyakit dan parasit yang makin tinggi; (2) berkurangnya kehadiran simbion pada sistem perakaran dan meningkatnya dominasi simbion yang kurang bermanfaat bagi tanaman; (3) penurunan keanekaragaman spesies atau perubahan komposisi jenis; (4) penurunan produksi primer bersih dan produksi ekosistem bersih; (5) pelimpahan transfer produksi tahunan ke dalam sistem dekomposisi; (6) laju respirasi tanaman atau komunitas yang makin tinggi; (7) defisiensi hara esensial untuk pertumbuhan karena ekosistemnya tidak mampu memanfaatkan, menjaga dan mengembalikan unsur hara tersebut serta munculnya gejala "bottleneck" suatu unsur hara dalam jangka panjang (Vogt et al. 1996).

Kondisi tertekan merupakan unsur vital bagi tiap tingkatan organisme biologis. Kemampuan bereaksi terhadap tekanan merupakan karakter penting bagi sistem kehidupan untuk bertahan hidup. Tidak ada perkembangan spesies dan ekosistem tanpa adanya tekanan alami. Namun, jangka waktu evolusi yang terjadi berada dalam selang variasi tekanan yang secara umum relatif konstan dan memberikan kesempatan spesies tersebut untuk mengatur ulang terhadap perubahan kondisi lingkungan (Merkert et al. 2003). Perubahan ekosistem akan memicu perubahan biologis dan ekologis organisme yang terdapat di dalamnya dari tingkat sel sampai komunitas (Vogt et al. 1996; Genet et al. 2001).

Suatu organisme akan berkembang secara optimal pada kondisi lingkungan yang ideal. Komponen ekosistem yang tidak normal berdampak pada perubahan mekanisme kerja pada suatu organisme. Beberapa organisme mampu memberikan tanggapan (Weissman et al. 2006), pertanda (Elliot 1997), peringatan dini (Jones \& Eggleton 2000), atau representasi (Hilty \& Merylender 2000; Vanclay 2004) serta refleksi (Vogt et al. 1997; Didden 2003; Vanclay 2004), informasi (McGeoch 1998) terhadap perubahan kondisi lingkungan. Kemampuan organisme tersebut dalam memberikan kemampuan tersebut 
merupakan salah satu komponen penting dalam pengelolaan ekosistem. Organisme tanggapan ini umumnya dikenal sebagai bioindikator. Organisme indikatif atau bioindikator memiliki hubungan yang erat antara organisme tersebut dengan perubahan komponen abiotik dan biotik pada suatu ekosistem (McGeoch et al. 2002).

Makalah ini bertujuan untuk mengevaluasi dan mengkaji peranan rayap sebagai bioindikator berdasarkan kajian literatur yang ada.

\section{DASAR DAN KONSEP BIOINDIKATOR}

Bioindikator adalah organisme (atau bagian dari suatu organisme ataupun suatu komunitas organisme) yang memiliki informasi tentang kualitas suatu kondisi lingkungan atau sebagian dari komponen lingkungan (Mhatre \& Pankhurst 1997; Kettrup 2003) yang digunakan untuk menjelaskan pengaruh-pengaruh perubahan lingkungan pada skala ruang dan waktu (Markert et al. 2003) ataupun kondisi lingkungan sehingga sering diacu sebagai indikasi tekanan lingkungan yang bersifat antropogenik (Franzle 2003)

$$
\text { Sedangkan, McGeoch }
$$

mendefinisikan bioindikator sebagai spesies atau kelompok spesies yang secara cepat dapat menggambarkan kondisi lingkungan baik abiotik maupun biotik; atau menggambarkan dampak perubahan lingkungan dari sebuah habitat, komunitas atau ekosistem; atau mengindikasikan keragaman dari kelompok takson, atau keragaman secara keseluruhan di dalam suatu habitat. Bioindikator adalah organisme yang menunjukan sensitivitas atau toleransi terhadap kondisi lingkungan sehingga memungkinkan untuk digunakan sebagai alat penilai kondisi lingkungan. Spesies indikator adalah spesies yang memiliki tanggapan terhadap satu atau beberapa pengaruh faktor lingkungan yang sempit (McGeoch 1998).

Bioindikasi menurut McGeoch (1998) dalam penerapannya dapat dikelompokan ke dalam tiga kategori yaitu:

1. Indikator lingkungan (environmental indicators) adalah spesies atau kelompok spesies yang tanggap terhadap kondisi lingkungan yang rusak atau perubahan kondisi lingkungan. Organisme ini dapat digunakan untuk menduga dan memonitoring perubahan kondisi lingkungan fisika dan kimia. Indikator lingkungan dibagi lagi menjadi 5 yaitu sentinels, detektor, eksploiter, akumulator dan bioassay organisms.

2. Indikator ekologis (ecological indicators) yaitu karakteristik takson atau kelompok yang peka dalam mengidentifikasikan faktor-faktor yang terdapat dalam ekosistem. Organisme ini mampu menggambarkan pengaruh dari tekanan-tekanan ini terhadap biota dan tanggapannya diwakili oleh sedikit takson yang ada pada habitat tersebut. Organisme ini juga dapat memonitor pengaruh stressor terhadap perubahan kondisi biota dalam jangka panjang.

3. Indikator keanekaragaman hayati (biodiversity indicators) adalah kelompok takson atau kelompok fungsional dimana keragamannya dapat menggambarkan beberapa ukuran tentang keragaman (kayaan jenis, kekayaan sifat dan endemisitas) takson di atasnya dalam sebuah habitat atau kelompok habitat sehingga fungsinya dapat digunakan untuk mengidentifikasi keragaman hayati ataupun memantau perubahan 
keragaman hayati. Sehingga indicator keanekragaman hayati dapat digunakan untuk penilaian habiatat dalam biologi konservasi. Indikator biodiversitas dapat dibedakan menjadi tiga kelompok yaitu kelompok referensi, kelompok kunci dan kelompok focal.

Kriteria umum untuk menetapkan suatu organisme digunakan sebagai bioindikator adalah (1) takson yang lebih tinggi dan/atau dipilih takson yang telah diketahui secara rinci dan taksonominya jelas serta mudah untuk diidentifikasi; (2) sifat-sifat biologi organisme tersebut diketahui dengan baik dan memiliki tanggapan yang baik terhadap faktor-faktor tekanan atau perubahan habitat; (3) organisme tersebut tersedia secara melimpah, mudah disigi dan dimanipulasi (dilakukan perlakuan tertentu) tertentu; (4) organisme tersebut tersebar dalam ruang dan waktu atau bersifat kosmopolitan; dan (5) berkorelasi kuat dengan keseluruhan komunitas dan/atau dengan faktor-faktor tekanan lingkungan (Hodkinson \& Jackson 2005).

Bioindikasi dapat meliputi beberapa variasi skala dari aspek makromolekul, sel, organ, organisme, populasi, sampai biocoenosis (ekosistem). Sehingga bentuk bioindikasi meliputi:

(1) reaksi biokima dan fisiologis; penyimpangan bentuk anatomis, morfologis, irama biologis, dan tingkah laku dari kondisi normalnya, (3) perubahan floristik, faunistik, dan populasi secara berurutan, (4) perubahan ekosistem ataupun kombinasi ekosistem, (5) perubahan bentuk dan fungsi ekosistem, dan (6) perubahan dari sifat bentang alam (Mhatre \& Pankhurst 1997).
Tipe indikator secara umum dibedakan menjadi tiga kelompok yaitu: (1) Indikator (kehadiran dan ketidakhadiranya menyimpulkan tentang permasalahan lingkungan, namun secara kuantitatif jarang ditemukan). (2) spesies uji (tanggapannya mengindikasikan tentang permasalahan yang luas, spesies uji umumnya memiliki standardisasi yang tinggi), (3) monitor (menyediakan bukti akan adanya perubahan, kesimpulan kuantitatif biasanya memungkinan jika dilakukan kalibrasi). Monitor terdiri dari monitor aktif (organisme monitor yang tersedia dengan cepat di alam) dan monitor pasif (organisme monitor yang diintroduksi). Monitor pasif terdiri dari reaktor (tanggapannya ditunjukan dengan perubahan fungsi atau reaksi) dan akumulator yang tanggapannya diamati berdasarkan akumulasi polutan yang tersinpan di dalam organism tersebut (Hornby \& Bateman 1997).

Pengembangan sistem bioindikator dapat dilihat sebagai hubungan timbal balik antara faktor lingkungan dengan komponen-komponen biologis. Karakteristik biologis diantaranya adalah komposisi jenis, gejala kerusakan suatu organisme, tubuh yang terkontaminasi polutan, induksi dan penghambatan enzim (Straalen 1997). Franzle (2003) menjelaskan bahwa tanggapan suatu organisme terhadap pengaruh lingkungan dapat diamati dari tingkat molekular (Gambar 1). Efektivitas suatu bioindikator tergantung pada kekuatan hubungan antara faktor-faktor lingkungan dan ciri-ciri biologis suatu organisme. Faktor lingkungan mempengaruhi ciriciri biologis melalui beberapa hubungan kausatif. Ketika ciri-ciri biologis dijadikan sebagai indikator, maka parameter biologis adalah pemicunya (Straalen 1997). 
Waktu (S)

Ruang $\left(\mathrm{m}^{2}\right)$

$10^{0}$

\begin{tabular}{|l|l|l}
$\begin{array}{l}\text { tiba-tiba - } \\
\text { beberapa } \\
\text { hari }\end{array}$ & $\begin{array}{l}\text { Gangguan } \\
\text { Gejala neurologis dan endokrin } \\
\text { Kemofoto dan geotaksis, } \\
\text { Orientasi, motilitas }\end{array}$ \\
&
\end{tabular}

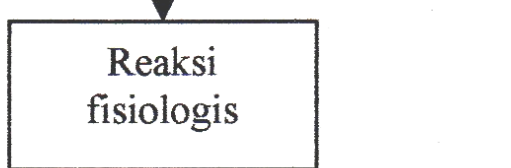

Depleksi $\mathrm{O}_{2}$, proses osmotik

Dan ionik, pengambilan

Makanan, pencernaan,

Ekskresi, fotosintesis

nitrifikasi

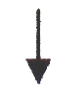

Reaksi biokimia

aktivitas enzimatis dan

metabolisme, induksi MFO,

sistesis asam amino dan

hormon steroid, mutasi DNA

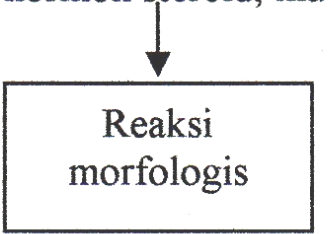

perubahan jaringan, pembentukan tumor, deformasi

$10^{-9}$

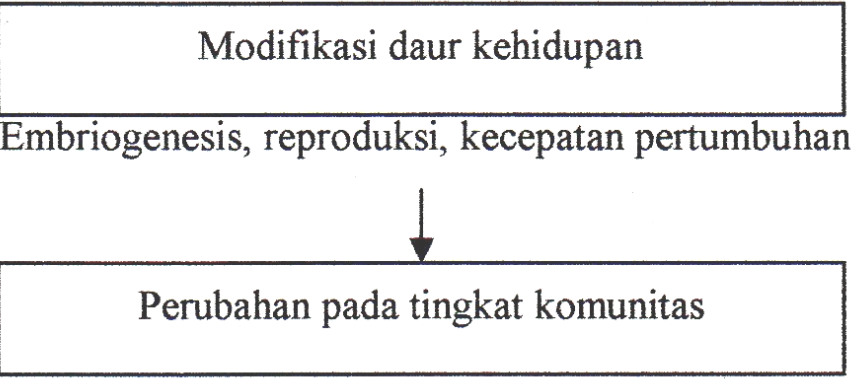

Penyusutan kelimpahan, perubahan struktur umur

dan sumber daya genetik

tahun

Perubahan pada tingkat ekosistem

Perubahan struktur dan dinamika pada komunitas dan ekosistem

Gambar 1. Tingkat tanggapan sistem biotik terhadap tekanan terkait dengan ukuran dan kompleksitas sistem tersebut (Franzle 2003). 


\section{RAYAP SEBAGAI ORGANISME BIONDIKATOR}

Rayap merupakan mesofauna tanah utama di kawasan tropis (Lee \& Wood 1971, Bignel \& Egglenton 2000). Rayap merupakan salah satu ecosystem engineers yang berperan sebagai penghubung siklus biogeokimia dan menghubungkan interaksi antara konsumen dan produsen. Rayap memiliki kemampuan untuk mengolah tanah, mencampur bahan organik dan mineral serta mengkonservasinya agar tetap tersedia sekaligus memperbaiki struktur tanah (Lee \& Wood 1971; Bignell \& Eggleton 2000). Rayap merupakan dekomposer utama daerah tropik yang berperan dalam dehumifikasi dan mineralisasi bahan organik karena kemampuan mereka untuk mengkonsumsi selulosa yang terkandung di dalamnya (Bignell \& Eggleton 2000). Rayap membantu penyediaan sumber daya bagi organisme lain baik secara langsung maupun tidak langsung (Jones et al. 1997 di dalam Lavelle \& Spain 2001). Walaupun, berukuran badan kecil rayap juga berperan dalam biodiversity (keanekaragaman hayati) karena kemiripan antar jenis dalam satu suku sangat tinggi.

Rayap merupakan salah satu organisme bioindikator yang potensial dikembangkan pada era bioindikator. Rayap, semut dan kupu-kupu heliconida merupakan tiga kelompok serangga indikator terbaik berdasarkan perananya di dalam ekosistem, tingkat tanggapan terhadap gangguan pada ekosistem dan tingkat asosiasi dengan organisme yang lain (Brown 1991 di dalam Speight et al. 1999). Rayap menunjukan korelasi yang positif terhadap keanekaragaman takson yang lain pada habitat yang sama (Vanclay 2004).
Selain itu, rayap juga menunjukan sensitivitas yang tinggi terhadap pengaruh kondisi lingkungan baik biotik maupun abiotik yang memaparnya serta proses-proses yang terjadi di dalam ekosistem (Jones \& Eggleton 2000).

Pembukaan kawasan berhutan pada umumnya mengakibatkan penurunan kelimpahan rayap, biomassa dan kekayaan jenis rayap secara cepat. (Eggleton \& Bignel 1995; Eggleton et al. 1995; 1996). Kekayaan jenis rayap pada suatu ekosistem berkorelasi negatif dengan tingkat gangguan pada ekosistem tersebut (Eggleton et al. 1995; 2002). Penelitian Jones et al. (2003); Gillison et al. (2003) ditemukan sekitar 34 jenis pada hutan primer dan menurun sampai hanya ada 1 spesies di kebun tipe monokultur. Beberapa penelitian juga menunjukan fenomena yang sama dimana kekayaan jenis rayap pada kawasan yang relatif masih belum terganggu memiliki kekayaan jenis yang lebih tinggi dibandingkan dengan kawasan lain yang sudah terganggu (Eggleton et al. 1995; 1996; 1999; Jones \& Prasetyo 2002; Jones et al. 2003; Gillison et al. 2003).

Tipe fungsional (jenis bahan makanan) rayap juga mengalami perubahan komposisi ketika suatu kawasan berubah menjadi ekosistem yang lebih sederhana (Bignell \& Eggleton. 2000). Hutan yang telah mengalami pembukaan dominasi rayap pemakan material tanah (kandungan bahan organik rendah) digantikan oleh keberadaan rayap pemakan kayu (Bignel \& Eggleton 2000; Jones et al. 2003). Rayap pemakan kayu cenderung meningkat jumlahnya sedangkan komposisi jenis rayap pemakan material tanah menurun dengan drastis (Eggleton et al. 2002). Kelimpahan relatif dari rayap pemakan kayu juga menunjukan kelimpahan yang 
lebih tinggi dibandingkan rayap pemakan material tanah (Jones \& Prasetyo 2002; Jones et al. 2003). Secara umum keanekaragaman rayap menurun dan muncul dominasi oleh suatu jenis rayap.

Fenomena ini secara umum terkait dengan karakteristik fisiologis dan morfologis dari rayap. Rayap merupakan organisme yang sangat rentan terhadap perubahan lingkungan. Relatif kecil, lemah dan peka terhadap cahaya dan kelembaban. Aktivitas rayap sangat dipengaruhi oleh berbagai faktor, seperti tanah, tipe vegetasi, faktor iklim dan ketersedian air. Sistem pertahanan rayap merupakan organisme komunal, sehingga rayap sangat tergantung satu sama lain. Menurut Bignell \& Eggleton (2000) pengurangan keanekaragaman rayap disebabkan oleh perubahan kondisi lingkungan seperti perubahan habitat mikro akibat penurunan penutupan tajuk dan terjadinya peningkatan bulk density.

\section{PENERAPAN RAYAP SEBAGAI BIOINDIKATOR DI LAPANGAN}

Metode sigi rayap untuk daerah tropis telah ditetapkan sebagai kesepakatan para ilmuwan. Metode transect surveys yang dikembangkan oleh Eggleton dan Jones (2000) dapat digunakan untuk mengamati karakter ekologis rayap sebagai protokol baku pengamatan keanekaragaman rayap. Metode ini relatif cepat untuk menilai kekayaan jenis rayap pada suatu kawasan, pola spasial dan temporal dari struktur komposisi rayap di hutan tropis sekaligus mendukung pengamatan rayap sebagai bioindikator. Data yang diperoleh dari metode ini adalah komposisi taksonomi dan kelompok fungsional rayap (Eggleton et al. 2002; Jones et al. 2006).
Penggunaan indeks heterogenitas sering digunakan untuk menafsir nilai indikasi suatu organisme terhadap kondisi habitat. Indeks kemerataan (evenness) juga dapat digunakan sebagai parameter nilai indikasi suatu organisme bioindikator. Perbedaan dari masing-masing indeks antar habitat merupakan pembanding yang memadai untuk menilainya. Analisis pembanding bisa digunakan anova ataupun korelasi dan regresi. Pemanfaatan analisis multivariat juga dapat digunakan untuk menjelaskan pengaruh dari komponen lingkungan terhadap keanekeragaman ataupun kesamaan dari masingmasing spesies antar habitat.

Nilai indikator suatu jenis yang cukup akurat untuk menguji nilai indikasi suatu jenis terhadap ekosisten adalah nilai indikator (Indicator value) yang dikembangkan oleh Dufrene \& Legendre (1997). Nilai indikator suatu jenis dinilai berdasarkan fidelitas dan spesifitasnya (Dufrene \& Legendre 1997; McGeoch et al. 2002). Fidelitas (fidelity) adalah frekuensi kehadiran suatu jenis di sepanjang habitat atau ekosistem yang umumnya berasosiasi dengan kelimpahannya (McGeoch et al. 2002), sedangkan spesifisitas (specificity) adalah kekhususannya pada suatu habitat atau ekosistem atau pola distribusi suatu jenis terhadap suatu habitat (Duelli \& Obrist 2003).

Nilai indikator yang lain yang dapat digunakan adalah Twinspan yang dikembangkan oleh Hill (1979). Metode lain adalah dengan menggunakan Index of Biological Integrity (IBI) yang dikembangkan oleh Karr pada tahun 1981) Namun IBI sering digunakan pada ekosistem aquatik, jarang digunakan pada ekosistem terestrial. 


\section{DAFTAR PUSTAKA}

Becker PH. 2003. Biomonitoring with birds. Di dalam: Merkert BA, Breure AM, Zechmeister HG. 2003. Bioindicator and Biomonitoring Principles, Concepts and Applications. Amsterdam: Elsevier Science. Hal: $677-736$.

Bignell DE, Eggleton P. 2000. Termites in ecosystems. Di dalam: Abe T, Bignell DE, Higashi M. Termites Evolution, Sociality, Symbioses, Ecology. Dordecht: Kluwer Academic. Hal: 363 - 387.

Didden W. 2003. Oligochaeta. Di dalam: Merkert BA, Breure AM, Zechmeister HG. 2003. Bioindicator and Biomonitoring Principles, Concepts and Applications. Amsterdam: Elsevier Science. Hal: 555 - 576.

Eggleton $\mathrm{P}$, et al. 2002. Termite diversity a cross an anthropogenic disturbance gradient in humid forest zone of West Africa. Agric Ecos Environ 90: 189-202.

Elliot ET. 1997. Rationale for developing bioindicator of soil health. Di dalam: Pankhurst CE, Doube BM, Gupta VVSR, editor. Biological Indicator of Soil health. New York: CABI.

Genet JA, Genet KS, Burton TM, Murphy PG, Lugo AE. 2001. Response of termite community and wood decomposition rates to habitat fragmentation in subtropical dry forest. Trop Ecol 42 (1): 35 - 49.

Gillison AN, Jones DT, Susilo FX, Bignell DE. 2003. Vegetation indicates diversity of soil macroinvertebrates: a case study with termites along a land-use intensification gradient in lowland Sumatra. Organisms Divers Evol 3: 111 - 126.

Hilty J, Merenlender A. 2000. Faunal indicator taxa selection for monitoring ecosystem health. Biol Con 92: 185-197.

Hodkinson ID, Jackson JK. 2005. Terrestrial and aquatic invertebrates as bioindicators for environmental monitoring, with particular reference to mountain ecosystems. Environ Manag 35 (5): 649 - 666.
Hornby D, Bateman GL. 1997. Potential use of plant root pathogens as bioindicators of soil health. Di dalam: Pankhurst CE, Doube BM, Gupta VVSR, editor. Biological Indicator of Soil health. New York: CABI. hlm: $179-200$.

Jones DT, Eggleton P. 2000. Sampling termite assemblages in tropical forest: testing a rapid biodiversity assessment protocol. $J$ of Appl Ecol 37: 191-203.

Jones DT, Prasetyo AH. 2002. A survey termites (Insecta: Isopteran) of Tabalong District, South Kalimantan, Indonesia. The Raffles Bull of Zool 50 (1): 117 - 128.

Jones DT et al. 2003. Termite assemblage collapse a long a land-use intensification gradient in lowland central Sumatra, Indonesia. J of Appl Ecol 40: 380 - 391.

Lavalle P, Spain AV. 2001. Soil Ecology. Amsterdam: Kluwer Academic Pr.

Lee KE, Wood TG. 1971. Termite and Soil. London : Academic Press.

McGeoch MA. 1998. The selection, testing, and application of terrestial insects as bioindicator. Biol Rev 73: 181-201.

McGeoch MA, Rensburg BJ van, Botes A. 2002. The verification and application of bioindicators: a case study of dung beetles in a savanna ecosystem. $J$ Appl Ecol 39: 661-662.

Merkert BA, Breure AM, Zechmeister HG. 2003. Definition, strategies and principles for bioindicator/biomonitoring of the environment. Di dalam: Merkert BA, Breure AM, Zechmeister HG, editor. Bioindicator and Biomonitoring Principles, Concepts and Applications. Amsterdam: Elsevier Science. hlm: 3 - 39.

Mhatre GN, Pankhurst CE. Bioindicator to detect contamination of soils with reference to heavy metal. Di dalam: Pankhurst CE, Doube BM, Gupta VVSR, editor. Biological Indicator of Soil health. New York: CABI. hlm: $349-369$. 
Pankhurst CE, Doube BM, Gupta VVSR. 1997.

Biological Indicator of Soil health: Synthesis. Di dalam: Pankhurst CE, Doube BM, Gupta VVSR, editor. Biological Indicator of Soil health. New York: CABI. hlm: $419-435$.

Straalen NM van. 1997. Community structure of soil arthopods as bioindicator of soil health. Di dalam: Pankhurst CE, Doube BM, Gupta VVSR, editor. Biological Indicator of Soil health. New York: CABI. hlm: $235-264$.

Vanclay JK. 2004. Indicator groups and faunal richness. Fbmis 1: 105-113.

Vogt KA, et al. 1996. Ecosystem Balancing Science with Management. New York: Springer-Verlag.

Weissman L,Fraiber M, Shine L, Garty J, Hochman A. 2006. Responses of antioxidants in the lichen Ramalina lacera may serve as a nearly warning bioindication system for detection of air pollution stress. Fems Microbiol Ecol 58: 41-53. 